\title{
Identification of laminin binding proteins in cell membranes of a human colon adenocarcinoma cell line
}

\author{
A Stallmach, D Schuppan, J Dax, C Hanski, E O Riecken
}

\begin{abstract}
The invasion of malignant cells through the basement membrane is a critical step in local infiltration and metastasis. Adhesion and invasion of malignant cells may be modulated by their receptor mediated binding to the basement membrane glycoprotein laminin. We studied the specific adhesion of human colon adenocarcinoma derived HT 29 cells to laminin and its proteolytic fragments. The major cell adhesion domain of laminin was localised in the central part of the cross shaped molecule. Immunoblotting experiments on separated HT 29 cell membranes using specific antibodies or radiolabelled laminin fragments revealed two major laminin-binding cell surface components with $M_{r}$ of 67000 and $69000 \mathrm{D}$ similar to the putative laminin receptor described for other tissues. Using a nitrocellulose filter disk assay, the specific interaction between cell surface binding proteins and proteolytic fragments originating from the central core of the laminin molecule could be further corroborated. In contrast, interaction of HT 29 cell membranes with the pentapeptide YIGSR (tyr-ile-gly-ser-arg), a sequence domain of the B1-chain of the laminin molecule, thought to be responsible for cell adhesion, was significantly weaker.
\end{abstract}

The interaction of malignant cells with basement membranes plays an important role in their metastatic spread. ${ }^{12}$ Invasive carcinomas, including colorectal carcinomas, are characterised by the loss of an intact basement membrane. Basement membranes are electron dense, 20-100 nm thick layers of which collagen type IV, heparan sulphate proteoglycan, nidogen, and laminin are the major known components. Laminin, their most prominent glycoprotein, exhibits a number of biological activities including promotion of attachment, migration, growth, and differentiation of certain cells. These properties of laminin are related to its potential for cell binding. In this respect several cell surface laminin binding proteins have been characterised. The best known of these is a cell surface receptor with a molecular mass ranging between 65000 and $72000 \mathrm{D}$ found in a variety of tissues and cell lines including tumour, ${ }^{4-}$ skeletal muscle, ${ }^{7}$ and placental cells. ${ }^{8}$ There is evidence to suggest that other cell surface proteins with $\mathrm{M}_{\mathrm{r}}$ of $120000 \mathrm{D}$ and $180000 \mathrm{D}^{910}$ respectively, and a cell surface protein with a $M_{r}$ of $140000 \mathrm{D}$ as a member of the integrin family of adhesion receptors ${ }^{11}$ may also function as laminin receptors. Laminin is made up by one A-chain $\left(M_{r}=440000\right)$, a B1-chain and a
B2-chain $\left(M_{r}=210000 \mathrm{D}\right.$ and $230000 \mathrm{D}$, respectively)..$^{1213}$ In the cross-shaped structure of laminin each of the A- and B-chains forms one short arm, and the rest of the three chains together project down the long arm. ${ }^{14}$ is Immunological, electronmicroscopical and cell culture studies with laminin fragments have shown that the central part of the molecule is responsible for cell adhesion. ${ }^{+16}$ In addition to promoting cell adhesion central fragments of laminin also decrease the metastatic potential of tumour cells presumably by saturation of laminin receptors thought to be involved in tumour cell invasion through basement membranes. ${ }^{17}$ Other functional domains of the laminin molecule have been described. Thus, the terminal part on the long arm contains a heparin binding domain, ${ }^{18} 19$ and the distal end of the long arm has been recognised to have a high affinity cell domain, which stimulates cell spreading. ${ }^{20}$

Recent studies indicate that laminin promotes adhesion and proliferation of intestinal epithelial cells in vitro ${ }^{22}$ (submitted data). The identification of cell surface molecules mediating these cell matrix interactions may help to elucidate the mechanisms by which malignant intestinal tumour cells encounter and trasverse the subepithelial and vascular basement membranes. ${ }^{23}$

In the present investigation we analyse the interaction of human colon adenocarcinoma derived HT 29 cells with laminin in vitro. Cell membranes were also isolated and binding assays with various fragments of laminin and the synthetic laminin peptide Tyr-Ile-Gly-Ser-Arg (YIGSR) were performed. We found that the adhesion of HT 29 cells to laminin occurs through the cell binding domain in the central part of the laminin molecule. In addition, two major laminin cell surface binding proteins of $M_{r}$ 67000 and $69000 \mathrm{D}$ in HT 29 cell membranes were identified, which were similar to the 67000 $\mathrm{D}$ laminin receptor described for other tissues.

\section{Methods}

\section{CELL CULTURES}

The human colon adenocarcinoma cell line HT 29 was obtained from the American Type Culture Collection (ATCC, USA) and was used between the 154th and 160th passage. HT 29 cells were routinely cultured in Dulbecco's modified Eagle's medium (DMEM) $(4.5 \mathrm{~g} / 1$ glucose) (Boehringer, Mannheim, FRG) supplemented with $10 \%$ heat-inactivated fetal calf serum (Biochrome, Berlin (West)) in $8 \% \mathrm{CO}_{2}$ in air at $36^{\circ} \mathrm{C}$. Media were changed routinely three times a week. 
PREPARATION OF SUBSTRATES AND FRAGMENTS

C57 Black mice were injected subcutaneously with EHS sarcoma cells. ${ }^{24}$ After three to seven weeks well encapsulated tumours were harvested, minced into small pieces and immediately placed into ice cold $4 \mathrm{M} \mathrm{NaCl}, 0 \cdot 2 \mathrm{M}$ Tris- $\mathrm{HCl}$ buffer, $\mathrm{pH} 7 \cdot 2$, containing as protease inhibitors $10 \mathrm{mM}$ ethylenediaminetetraacetic acid, $4 \mathrm{mM}$ $\mathrm{N}$-ethyl maleimide (NEM) and $0.5 \mathrm{mM}$ phenylmethylsulphonyl fluoride (PMSF), and washed twice with a 10 -fold volume for one hour on ice. The preextracted tumour matrix was stirred for two hours and then another 16 hours with 4 volumes each of $2 \mathrm{M}$ guanidin, $0.5 \mathrm{M} \mathrm{NaCl}, 0 \cdot 2$ $\mathrm{M}$ Tris- $\mathrm{HCl}, \mathrm{pH} \mathrm{7} \cdot 4$, and protease inhibitors (see above) as described by Hahn et al (submitted data). Laminin was purified from the guanidin extract by the procedure described by Timpl et $a l^{3}$ using DEAE (Whatman, FRG) and Sephacryl S-400 (Pharmacia, Sweden) chromatography. Laminin was cleaved with pepsin or trypsin (Tyrosyl-phenyl-chloromethyl-ketone treated, Serva, FRG) at an enzyme/substrate (w/w) ratio of $1: 50 . .^{25}$ Fragments $\mathrm{P1}$ and $\mathrm{P} 2$ from pepsin digests as well as fragments $\mathrm{T} 1$ and T4 from trypsin digests were further purified by chromatography on DEAE-cellulose, Sephacryl S-300 and heparin Sepharose (Pharmacia, Sweden). Purity was confirmed by SDS-PAGE before and after reduction and by amino acid analysis.

The synthetic laminin peptide YIGSR $\left(\mathrm{H}_{2} \mathrm{~N}\right.$ Tyr-Ile-Gly-Ser-Arg-OH) was obtained from Bissendorf Biochemicals (FRG). The purity of the peptide was greater than $99 \%$ as analysed by HPLC. Preparation of human collagen type IV (7-S long form and triple helical domain), and collagen type III followed published procedures. ${ }^{27} 28$

\section{ANTIBODY PREPARATION AND \\ CHARACTERIZATION}

High titre antisera against mouse laminin and human 7-S collagen (long form) were produced using standard protocols. ${ }^{2728}$ Antisera against laminin showed no cross reactivity with collagen type IV (7-S and NC-1 domains) by radioimmunoassays and affinity purified antibodies against human 7-S collagen (long form) have previously been shown to be monospecific. ${ }^{28}$

\section{ADHESION ASSAYS}

For cell adhesion assays, 10 microwells in 96well dishes (Falcon, Oxnard, USA) were incubated with $100 \mu \mathrm{l}$ phosphate buffered saline (PBS, pH 7-2) containing various amounts of either laminin, collagen type III, collagen type IV (triple helical and 7-S long domains) or bovine serum albumin (BSA) for 90 minutes at $36^{\circ} \mathrm{C}$, drained and washed once with PBS. By adding trace amounts of ${ }^{125}$ I-labelled substrate to the protein solution the efficiency of coating was shown to be comparable in all experiments. HT 29 cells were harvested by trypsinisation during the logarithmic phase of growth after a 24 hour incubation period in serum free medium. Cells in serum free medium were added to each dish $\left(10^{5} /\right.$ dish) and incubated for various times at $36^{\circ} \mathrm{C}$. At the end of the incubation period, plates were gently washed two times with $200 \mu \mathrm{l}$ PBS to remove unattached cells. After staining with Giemsa 10 areas of $4.25 \mathrm{~mm}^{2}$ in the centre of each dish was photographed (Yashica, Ilford HP 5 films), and adherent cells were counted from the photographs. Thus, a total of $42.5 \mathrm{~mm}^{2}$ was evaluated for each substrate and the mean of adherent cells was calculated. The affinity of HT 29 cells to different substrates was calculated as the percentage of adherent cells on substrate coated dishes compared with the amount of cells added to each dish.

To test for inhibition of adhesion to laminin, plates were coated with laminin $(5 \mu \mathrm{g} /$ well $)$. The cells were seeded onto laminin coated plates in various dilutions of laminin fragments $\mathrm{Pl}$ and $\mathrm{P} 2$, or of the peptide YIGSR in medium and incubated for three hours at $36^{\circ} \mathrm{C}$

Specificity of adhesion to laminin was tested by blocking the coated dishes with antilaminin and affinity purified anticollagen type IV (7-S long domain) antibodies in various dilutions for 60 minutes at $36^{\circ} \mathrm{C}$. After draining the plates and washing two times with PBS, HT 29 cells were seeded and the adhesion assay was carried out as described after a three hour incubation at $36^{\circ} \mathrm{C}$.

\section{PREPARATION OF CELL MEMBRANES}

HT 29 cell membranes were prepared as described by Maeda et al..$^{29}$ Briefly, confluent monolayers were washed twice with $\mathrm{PBS}\left(4^{\circ} \mathrm{C}\right)$, scraped from the culture dishes and centrifuged at $1000 \mathrm{~g}$ for 10 minutes. The pellet was resuspended in $0.01 \mathrm{M}$ triethanolamine hydrochloride, $\mathrm{pH} 7 \cdot 5$ (TEA-buffer) containing $8.5 \%$ sucrose, $1 \mathrm{mM}$ PMSF, and $1 \mathrm{mM} \mathrm{NEM}$ and homogenised on ice in a Potter homogeniser. The homogenate was loaded on a $41 \%$ solution of sucrose in TEA-buffer. After centrifugation at $95000 \mathrm{~g}$ for one hour in a Kontron TST 28.38 swing rotor, cell membranes were collected as a white interfacial band, diluted by adding a threeto-four fold excess of TEA-buffer, and pelleted by centrifugation at $95000 \mathrm{~g}$ for 30 minutes.

POLYACRYLAMIDE GEL ELECTROPHORESIS AND IDENTIFICATION OF LAMININBINDING MEMBRANE PROTEINS BY IMMUNOBLOTTING

Cell membranes were analysed by SDS-polyacrylamide gel electrophoresis in $10 \%$ gels..$^{30}$ For blotting experiments, samples were transferred to nitrocellulose as described by Towbin et al. ${ }^{31}$ To identify laminin binding components, nitrocellulose strips with blotted cell membranes were saturated with $3 \%$ defatted cow milk in $20 \mathrm{mM}$ Tris-HCl-buffer, $\mathrm{pH} 8 \cdot 2$, containing $0.9 \%$ $\mathrm{NaCl}, 20 \mathrm{mM} \mathrm{NaN}_{3}$ (Tris-buffer) for 30 minutes at $37^{\circ} \mathrm{C}$, washed in PBS and incubated with intact mouse laminin $(1 \mu \mathrm{g} / \mathrm{ml})$ in TEA-buffer containing $0 \cdot 1 \%$ desoxycholat $(\mathrm{pH} 7 \cdot 2)$ (TEADOC-buffer) overnight at room temperature. The strips were then washed with TEA-DOCbuffer followed by incubation with anti-laminin antibodies $(1 \mu \mathrm{g} / \mathrm{ml})$ overnight at $4^{\circ} \mathrm{C}$. Bound antibodies were detected with anti-rabbit-IgG- 


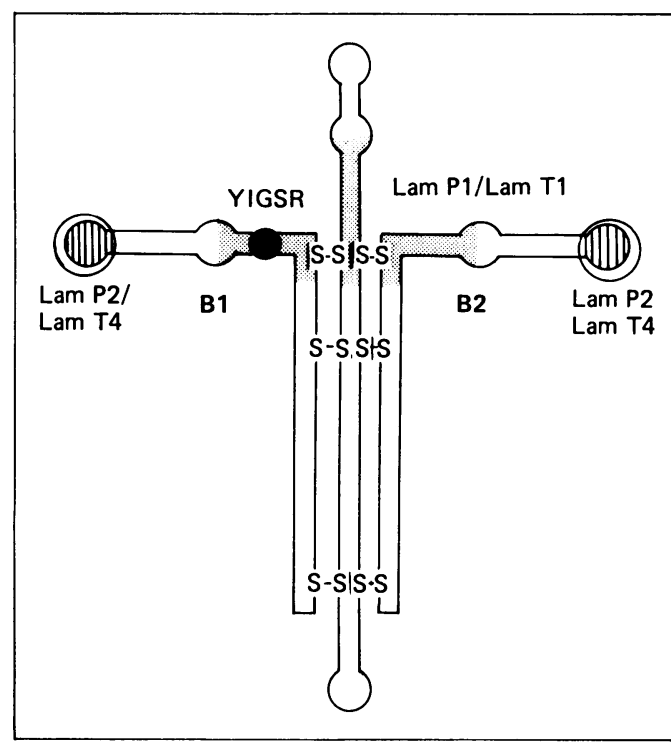

Figure 1: Structural model of the laminin molecule. Evidence for the assembly of the $A-, B 1-$, and B2-chains has been compiled elsewhere. ${ }^{8} 1012$ Hypothetical locations of interchain disulfide bonds are indicated $(S-S)$. Proteolytic laminin fragments $P 1$ and $P 2$ used in this study are hatched. The position of the pentapeptide YIGSR in the BI chain putatively interacting with the laminin receptor is denoted by a black spot.

antibodies (Janssen, Belgium) coupled to colloidal gold according to von der Mark and Risse. ${ }^{32}$ In a separate set of experiments, immunoblotted cell membranes were incubated with ${ }^{125}$ I-labelled murine or human laminin P1 fragment overnight at room temperature, washed three times in TEA-DOC-buffer, dried and exposed to $x$-ray films (Kodak).

\section{PROTEIN LABELLING}

Laminin fragments $\mathrm{P} 1, \mathrm{P} 2, \mathrm{~T} 1$, and $\mathrm{T} 4$ were labelled with ${ }^{125} \mathrm{I}(1 \mathrm{mCi} / 10 \mu \mathrm{g}$ antigen $)$ using the chloramine-T method..$^{33}$ The specific activity of labelled fragments was approximately $1-2 \times 10^{5}$ $\mathrm{cpm} / \mathrm{ng}$ protein.

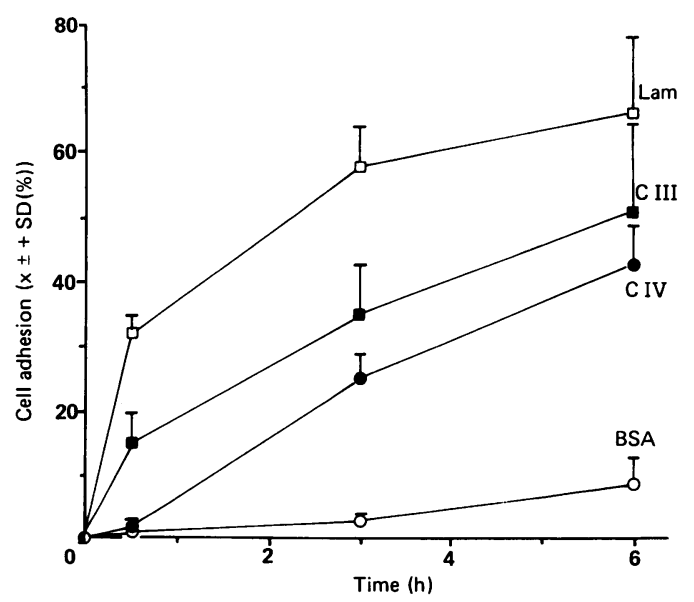

Figure 2: Time course for the adhesion of HT 29 cells to laminin (Lam), collagen type IV (C IV (triple helical and 7-S long domain)), collagen type III (C III) and bovine serum albumin $(B S A)$ in vitro at $36^{\circ} \mathrm{C}$. All dishes were coated with 5 $\mu \mathrm{g} / \mathrm{cm}^{2}$ of substrate for 90 minutes at $36^{\circ} \mathrm{C}$. At the indicated times, unattached cells were removed by washing, adherent cells stained by Giems a and counted. Each point represents the mean in relation to seeded cells (mean (SD) of three experiments).

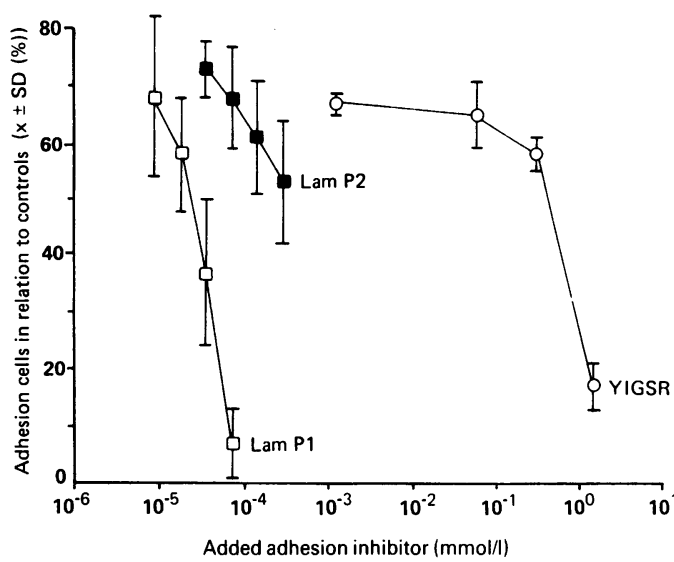

Figure 3: Effect of laminin fragments PI (Lam P1), P2 (Lam P2) and the synthetic pentapeptide YIGSR on adhesion of HT 29 cells to laminin. The cells were seeded onto laminin coated plates in various dilutions of laminin fragments $P l$ and $P 2$, or of the peptide YIGSR in serum-free medium and incubated for three hours at $36^{\circ} \mathrm{C}$. The adhesion assay was carried out as described in Methods.

\section{BINDING ASSAYS}

Binding of ${ }^{125} \mathrm{I}$-labelled laminin fragments $\mathrm{Pl}$, $\mathrm{P} 2, \mathrm{~T} 1$, and $\mathrm{T} 4$ to cell membranes immobilised on nitrocellulose filters was performed as described by Malinoff and Wicha. ${ }^{5}$ Briefly, various amounts of cell membranes (10-20 $\mu \mathrm{g}$ protein) were blotted onto nitrocellulose, and incubated in 3\% defatted cow milk in Tris-buffer. Then the strips were incubated with each laminin fragment $\left(2-5 \times 10^{5} \mathrm{cpm}, 2-5 \mathrm{ng}\right)$ in PBS containing $0.04 \%$ Tween 20 (PBS/Tween) for different times at room temperature followed by washing three times in PBS/Tween and counting in a gamma-counter.

Specificity of binding of labelled antigens to cell membranes in this assay was tested by addition of unlabelled intact laminin, laminin fragment P1, P2, or the synthetic peptide YIGSR at various concentrations.

\section{Results}

HT 29 CELLS PREFERENTIALLY ADHERE TO LAMININ

The adhesion of HT 29 cells to various substrates is remarkably different. Within three hours only $3 \%$ of the cells adhered to BSA in serum-free medium compared with $58 \%$ adhering to laminin. Interestingly, a significant adhesion was also observed to the interstitial collagen type III (35\%), and to pepsin solubilised collagen type IV (lacking the carboxy terminal propeptide; 25\%) (Fig 2). An incubation period of six hours increased this rate on collagen type III and IV to $51 \%$ and $43 \%$, respectively (Fig 2). Under all experimental conditions, however, HT 29 cells showed a preference for laminin rather than for the collagens type III and IV. Addition of serum to the cell suspension before assaying attenuated the differences between substrates (data not shown). To test the dose response relationship for laminin-mediated adhesion of HT 29 cells, plates were coated with laminin solutions of different concentrations. Laminin up to $2 \cdot 5$ $\mu \mathrm{g} / \mathrm{cm}^{2}$ clearly stimulated cell adhesion after which a plateau was reached (data not shown). 


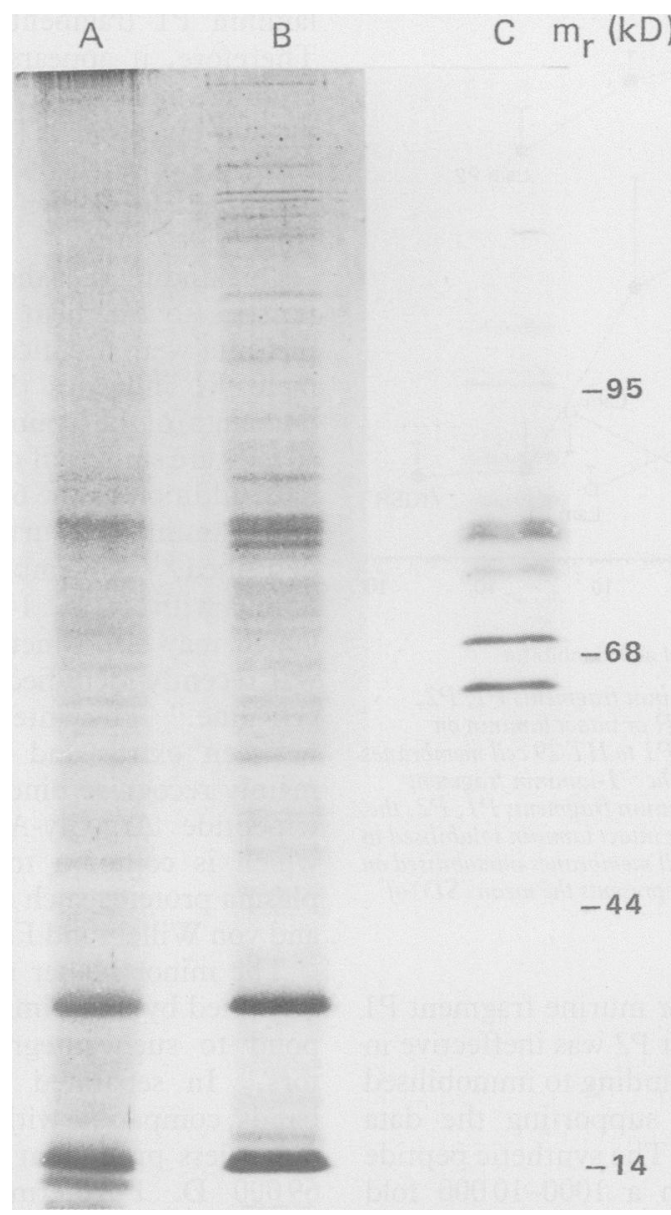

Figure 4: SDS-PAGE of HT 29 cell membranes (10\% gels) under non-reducing (lane $A$ ) and reducing conditions (lane $B$ ). Specific binding of laminin to two major bands with an $M_{\mathrm{r}}$ or 67000 and $69000 \mathrm{D}$ was shown after transfer of non-reduced cell membranes to nitrocellulose and incubation with laminin, followed by incubation with monospecific anti-laminin antibodies as described in Methods (lane $C$ ). Standards are phosphorylase $b\left(M_{\mathrm{r}} 95 \mathrm{kD}\right)$, bovine serum albumin $\left(M_{\mathrm{r}}\right.$ : $68 \mathrm{kD})$, ovalbumin $\left(M_{\mathrm{r}}: 44 \mathrm{kD}\right)$, and carbonic anhydrase inhibitor $\left(M_{\mathrm{r}}: 14 \mathrm{kD}\right)$.

We also studied the adhesion of HT 29 cells to laminin in the presence of affinity purified antilaminin- and anti-collagen type IV- (7-S long domain) antibodies in order to prove the specificity of the laminin action. Anti-laminin antibodies were dose dependent inhibitory suggesting that this interaction is specific, while no significant effect was noted with anti-collagen type IV antibodies (data not shown).

To more precisely define the HT 29 cell binding domain in the laminin molecule, we tested the effect of added laminin fragments P1, P2, or the synthetic peptide YIGSR (Fig 3). Cell adhesion to laminin was strongly inhibited by the addition of laminin fragment P1 from the central core of the laminin molecule in a dose dependent manner whereas fragment $\mathbf{P} 2$ originating from the periphery of the short arms was ineffective at comparable concentration (Fig 3). The inhibition with the pentapeptide YIGSR was about 10000 fold less effective in molar terms than with fragment P1 (Fig 3).

IDENTIFICATION OF LAMININ-BINDING PROTEINS BY IMMUNOBLOTTING

The presence of specific laminin binding com-
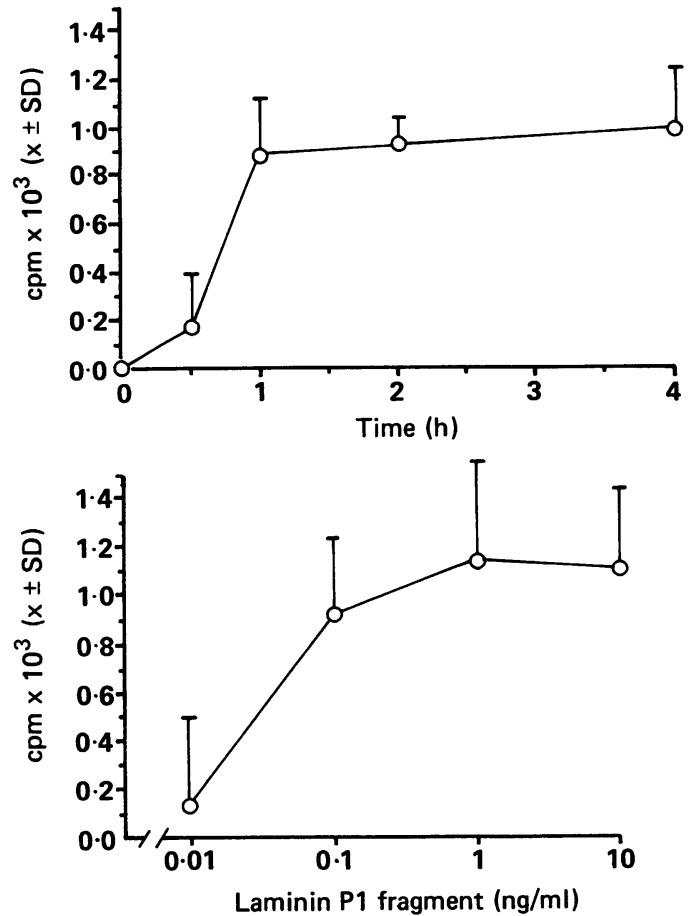

Figure 5: Binding ${ }^{125}$ I-labelled laminin Pl to immobilised HT 29 cell membranes. Ten micrograms of cell membrane protein was dot-blotted on nitrocellulose disks and binding assays were performed at $20^{\circ} \mathrm{C}$ as described in Materials and Methods. performed at $20^{\circ} \mathrm{C}$ as described in Materials and Methods. reveals that laminin $P 1$ bound to these cell membranes in a time $(A)$ and concentration dependent manner $(B)$.

ponents in the cell membranes of HT 29 cells was shown by immunoblotting experiments. After electrophoretical separation of cell membranes on $10 \%$ polyacrylamide gels under non-reducing conditions, laminin binding components were identified as two major bands with $M_{\mathrm{r}} 67000$ and $69000 \mathrm{D}$ (Fig 4). There were a number of minor bands migrating with mobilities of 72000 100000 and $110000-150000 \mathrm{D}$. Binding of laminin to reduced membranes revealed bands of similar mobilities, however, with a weaker reaction obviously caused by the loss of higher ordered protein structure necessary for receptor ligand interaction (data not shown). Incubation of nitrocellulose blots of separated cell membranes with ${ }^{125}$ I-labelled laminin fragment P1 revealed identical bands of laminin binding components after autoradiography (data not shown).

BINDING ASSAYS

To further test for the specificity of laminin binding to cell membrane components, binding assays for the HT 29 cell membrane fraction immobilised on nitrocellulose were performed. These membranes bound ${ }^{125}$ I-labelled human laminin fragment $\mathrm{Pl}$ in a time and concentrationdependent manner. Binding reached a maximum after 60 minutes at $20^{\circ} \mathrm{C}$ (Fig 5a) and was saturable (Fig 5b).

With $90(4) \%$ (mean (SD)) relative to binding of human P1 fragment, the murine fragment P1 bound comparatively well. Binding of equimolar amounts of murine laminin fragment P2 was only $11 \%(10) \%$ (mean (SD)), that for fragments $\mathrm{T} 1$ and $\mathrm{T} 461 \%(17) \%$ and 5 (4)\% respectively.

Binding of human laminin Pl to cell membranes could be inhibited by addition of un- 


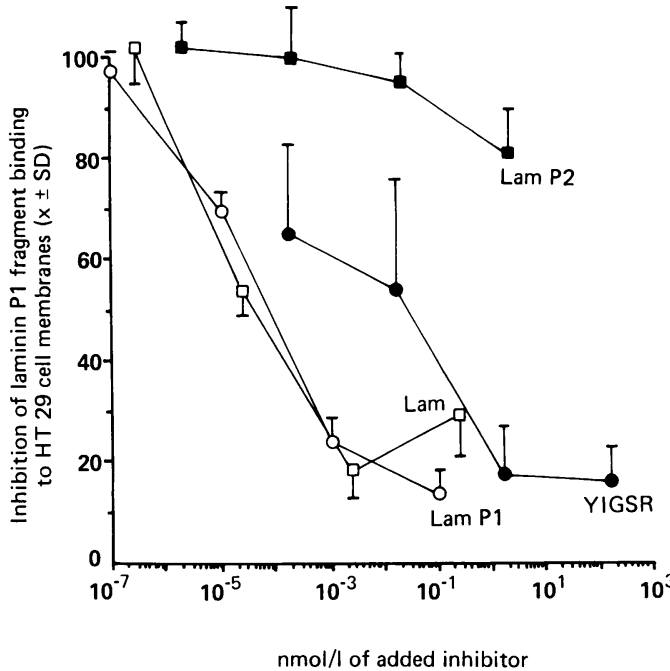

Figure 6: Inhibitory effect of laminin fragments $P 1, P 2$, the synthetic pentapeptide YIGSR or intact laminin on binding of ${ }^{125} I$-laminin fragment $P 1$ to HT 29 cell membranes $(10 \mu \mathrm{g} /$ disk $)$. Before addition of the ${ }^{125}$ I-laminin fragment $P 1$, varying concentrations of laminin fragments $P 1, P 2$, the synthetic pentapeptide YIGSR or intact laminin solubilised in PBS/Tween were added to the cell membranes immobilised on nitrocellulose disks. Each point represents the mean $(S D)$ of triplicate experiments.

labelled murine laminin or murine fragment P1 (Fig 6). Laminin fragment P2 was ineffective in inhibition of laminin Pl binding to immobilised cell membranes (Fig 6) supporting the data from cell adhesion assays. The synthetic peptide YIGSR inhibited only in a 1000-10000 fold molar excess over laminin fragment $\mathrm{Pl}$ (Fig 6) in accordance with its lack of inhibition of cell adhesion in vitro.

\section{Discussion}

The present study shows that the basement membrane glycoprotein laminin acts as a preferential substrate for attachment and spreading of human colon adenocarcinoma derived HT 29 cells. Pepsin soluble basement membrane collagen type IV and the interstitial collagen type III were less preferred substrates. Specificity of laminin as an adhesion molecule was shown by the ability of anti-laminin antibodies to prevent attachment and spreading of HT 29 cells in a dose dependent manner on laminin coated dishes. Furthermore, adhesion was competitively inhibited by the addition of murine laminin fragment $\mathrm{Pl}$ originating from the central part of the cross shaped laminin molecule. Fragment P2 originating from the periphery of the short arms of the molecule showed no such inhibition for HT 29 cell adhesion in accordance with previously reported results from hepatocytes. ${ }^{12}$

Immunoblotting experiments on separated HT 29 cell membranes revealed two major laminin binding components with a $M_{\mathrm{r}}$ of 67000 and $69000 \mathrm{D}$ as well as several minor bands with molecular weights of 72000-100000 and $110000-150000 \mathrm{D}$ (Fig 4). The characteristics of the two main bands are similar to those described for several normal and neoplastic cells. These cells were shown to react preferentially with laminin fragment $\mathrm{Pl}$ in competition assays with similar dissociation constants for laminin and laminin Pl fragment in radioligand binding. Therefore, it appears likely, that the laminin binding molecule(s) on the transformed intestinal epithelial HT 29 cells described by us correspond to the $67000 \mathrm{D}$ laminin receptor identified for other cells in these previous studies.

Our finding that the receptor binding characteristics to fragment $\mathrm{Pl}$ isolated from human placenta were identical to those of mouse fragment Pl indicates that the receptor binding domain(s) of the laminin molecule from different species are similar, if not identical.

In addition to the $67000 \mathrm{D}$ laminin receptor, other laminin cell surface binding proteins were described. ${ }^{910} \mathrm{~A}$ member of the integrin receptor family with an $M_{r} 140000 \mathrm{D}$ after reduction, which may also function as a laminin receptor was recently identified in a human glioblastoma cell line." The integrins serving as linkers between extra- and intracellular components mainly recognise binding sites that include the tripeptide Arg-Gly-Asp (RGD), a sequence which is common to many extracellular and plasma proteins such as fibronectin, vitronectin and von Willebrand Factor. ${ }^{34}$

The minor higher molecular mass gel bands identified by us by immunoblotting may correspond to such integrin-related laminin-receptors. ${ }^{11}$ In separated HT 29 cell membranes bands, compatible with integrins, however, were much less prominent than those of $M_{r} 67000 /$ 69000 D. Furthermore binding of labelled laminin fragment $\mathrm{Pl}$ to cell membranes could not be significantly inhibited by high concentrations of the tripeptide Arg-Gly-Asp (own unpublished results), suggesting that the integrins do only play a minor role in the interaction of HT 29 cells with laminin. Nevertheless, the presence of other laminin binding proteins may alter the affinity of cells for laminin or modulate their interaction with other extracellular matrix components. In this respect, it is an interesting finding, that in a melanoma cell line two functionally distinct laminin receptors mediate cell adhesion and spreading. ${ }^{35}$ Whether multiple receptor classes for laminin are unique to tumour cells and lead to an aberrant behaviour is an interesting but still unsolved question.

Laminin binding cell surface proteins may play a key part in cell adhesion of normal and neoplastic cells to basement membranes and in complex processes such as extravasation and metastasis. To metastasise, tumour cells must encounter and traverse the subepithelial basement membranes, migrate through the subepithelial connective tissue filled with cells and extracellular matrix components and enter the circulatory system. They must attach again to the extracellular matrix, preferentially to the vascular basement membrane, leave the circulatory system to be followed by a (clonal) proliferation in this secondary site. It was suggested ${ }^{23}$ that increased amounts of free laminin receptors on neoplastic cells facilitate adhesion to basement membranes. Their competitive blockade by the pentapeptide YIGSR, a sequence domain of the laminin fragment $\mathrm{Pl}$, thought to be responsible for the interaction with the laminin receptor, ${ }^{36}$ or by proteolytic fragments from the central core of 
the molecule reduce the formation of lung metastases. ${ }^{17}{ }^{37}$ In our in vitro experiments, however, the inhibitory capacity of the laminin pentapeptide YIGSR on cell adhesion was 10000 fold lower than that of fragment P1. Accordingly, the pentapeptide inhibited the binding of labelled fragments to cell membranes much less than fragment P1. On closer inspection, inhibition of experimental metastasis as reported by Iwamoto et $a l^{37}$ was only seen if neoplastic cells were pretreated with the pentapeptide YIGSR in high concentrations similar to those found effective in our studies casting some doubt on the significance of the specific interaction with the laminin receptor previously assigned to this peptide. ${ }^{36}$

The biochemical basis of basement membrane disruption during tumour invasion is poorly understood. This phenomenon involves a number of processes, including the degradation of epithelial cells such as the IEC-6- and colorectal factors and production of basement membrane components by malignant cells themselves. ${ }^{1} \mathrm{Al}-$ though completely undifferentiated intestinal epithelial cells such as the IEC- and colorectal carcinoma cell lines produce laminin and collagen type IV abundantly in monocultures, ${ }^{38} 39$ basement membrane synthesis in fetal intestinal epithelial mesenchymal cocultures and in vivo occurs mainly in the mesenchyme. ${ }^{4041}$ Biochemical studies on scirrhous carcinomas of human stomach suggest that mesenchymal cells are induced by infiltrating malignant epithelium to produce increased amounts of collagen type IV. ${ }^{42}$ Immunohistological analysis of cultured human intestinal biopsies from patients with chronic inflammatory bowel diseases or benign adenomas indicate that epithelial cells do not synthesise laminin. Surprisingly, laminin synthesis in primary epithelial cultures of colorectal carcinomas could be demonstrated immunohistologically (own unpublished results). The question, if malignant transformation of intestinal epithelial cells modifies the synthesis of basement membrane proteins is still open. In any case, the active participation of mesenchymal cells in basement membrane synthesis is of major importance in normal intestinal mucosa and malignant disease.

The present study shows high-affinity binding proteins for laminin with a $M_{r}$ of 67000 and $69000 \mathrm{D}$ in cell membranes of human adenocarcinoma derived colon cells. Further investigations on the expression of these laminin receptors in relation to the degree of epithelial cell differentiation/dedifferentiation may endow us with new promising tools for studying cell-matrix interactions in intestinal inflammation and neoplasia.

We are gratefully acknowledge the expert technical assistance of Doris Lazar. This work was supported by grant $\mathrm{Ri} 136 / 123-4$ of the Deutsche Forschungsgemeinschaft, Bonn-Bad Godesberg.

1 Liotta LA, Rao CV, Barsky SH. Tumor invasion and the extracellular matrix. Lab Invest 1983; 49: 636-9.

2 McCarthy JB, Basara ML, Palm SL, et al. The role of cell adhesion molecules - laminin and fibronectin - in the movement of malignant and metastatic cells. Cancer Metastasis Rev 1985; 4: 125-52.

3 Timpl R, Dziadek M. Structure, development and molecular pathology of basement membranes. Int Rev Exp Pathol 1986; 29: 1-112.

4 Terranova VP, Rao CN, Kalebic T, Margulies IM, Liotta LA
Laminin receptor on human breast carcinoma cells. Proc Natl Acad Sci USA 1983; 80: 444-8.

5 Malinoff $\mathrm{HL}$, Wicha MS. Isolation of a cell surface receptor protein for laminin from murine fibrosarcoma cells. $\mathcal{f}$ Cell Biol 1983; 96: 1475-9.

6 Rao CN, Barsky SH, Terranova VP, Liotta LA. Isolation of a tumor cell laminin receptor. Biochem Biophys Res Commun 1983; 111: 804-8.

7 Lesot H, Kühl U, von der Mark K. Isolation of a laminin binding protein from muscle cell membranes. $E M B O \mathcal{f}$ 1983; 2: 861-5.

8 Wewer UM, Liotta LA, Jaye M, Ricca GA, et al. Altered levels of laminin receptor mRNA in various human carcinoma cells that have different abilities to bind laminin. Proc Natl Acad Sci USA 1986; 83: 7137-41.

9 Smalheiser NR, Schwartz MB. Cranin: a laminin binding protein of cell membranes. Proc Natl Acad Sci USA 1987; 84: $6457-61$.

10 Kleinman HK, Ogle RC, Cannon FB, Little CD, Sweeny TM, Luckenbill-Edds L. Laminin receptors for neurite formation. Proc Natl Acad Sci USA 1988; 85: 1282-6.

11 Gehlsen KR, Dillner L, Engvall E, Ruoslahti E. The human laminin receptor is a member of the integrin family of cel adhesion receptors. Science 1988; 241: 1228-9.

12 Timpl R, Rohde H, Robey PG, Rennard SI, Foidart JM, Martin GR. Laminin - A glycoprotein from basemen membranes. F Biol Chem 1979; 254: 9933-7.

13 McCarthy JB, Skubitz APN, Palm SL, Furcht LT. Metastasis inhibition of different tumor types by purified laminin fragments and a heparin-binding fragment of fibronectin. fNCI 1988; 80: 108-15.

14 Engel J, Odermatt E, Engel A, et al. Shapes, domain organizations and flexibility of laminin and fibronectin. Two multifunctional proteins of the extracellular matrix. $7 \mathrm{Mo}$ Biol 1981; 150: 97-120.

15 Palm SL, McCarthy JB, Furcht LT. Alternative model for the internal structure of laminin. Biochemistry 1985; 24: 7753-60.

16 Rao CN, Margulies IM, Tralka TS, et al. Isolation of a subunit of laminin and its role in molecular structure and tumor cell attachment. F Biol Chem 1982; 257: 9740-4.

17 Barsky SH, Rao CN, Williams JE, Liotta LA. Laminin molecular domains which alter metastasis in a murine model. $\mathcal{F}$ Clin Invest 1984; 74: 843-8.

18 Roberts DD, Wewer UM, Liotta LA, Ginsburg V. Laminindependent and laminin independent adhesion of human

19 Aumailley M, Nurcombe V, Edgar D, Paulsson M, Timpl R. The cellular interactions of laminin fragments. Cell adhesion correlates with two fragment-specific high affinity binding sites. F Biol Chem 1987; 262: 11532-8.

20 Goodman SL, Deutzmann R, von der Mark K. Two distinct cell-binding domains in laminin can independently promote nonneuronal cell adhesion and spreading. I Cell Biol 1987; 105: 589-98.

21 Dillner L, Dickerson K, Manthorpe M, Ruoslahti L, Engval E. The neurite-promoting domain of human laminin promotes attachment and induces characteristics in morphology in non-neural cells. Exp Cell Res 1988; 177: 186-98.

22 Hahn U, Cho A, Schuppan D, Hahn EG, Merker HJ, Riecken EO. Intestinal epithelial cells preferentially attach to biomatrix from human intestinal mucosa. Gut 1987; 28 [suppl]: 153-8.

23 Liotta L, Rao CN, Wewer UW. Biochemical interactions of tumor cells with the basement membrane. Ann Rev Biochem 1986; 55: 1037-57.

24 Orkin RW, Gehron P, McGoodwin EB, Martin GR, Valentine T, Swarm R. A murine tumor producing a matrix of basement membrane. F Exp Med 1977; 145: 204-20.

25 Rohde H, Baechinger HP, Timpl R. Characterization of pepsin fragments of laminin in a tumor basement mempepsin fragments of laminin in a tumor basement mem-

26 Ott U, Odermatt E, Engel J, Furtmayr H, Timpl R. Protease resistance and conformation of laminin. Eur F Biochem 1982; 123: 63-72.

27 Schuppan D, Becker J, Boehm H, Hahn EG. Immunofluorescent localization of type V-collagen as a fibrilla component of the interstitial connective tissue of human ora mucosa, artery and liver. Cell Tissue Res 1986; 243: 535-43.

28 Becker J, Schuppan D, Hahn Albert G, Reichart P. Immunohistochemical distribution of collagen type IV, V, VI and of laminin in the human oral mucosa. Arch Oral Biol 1986; 3 : 179-86.

29 Maeda T, Balakrishnan K, Mehdi SQ. A simple and rapid method for preparation of plasma membranes. Biochim Biophys Acta 1983; 731: 115-20.

30 Laemmli UK. Cleavage of structural proteins during the assembly of the head of bacteriophage T 4 . Nature $1970 ; 227$ $680-5$.

31 Towbin H, Stachlin T, Gordon J. Electrophoretic transfer of proteins from polyacrylamide gels to nitrocellulose sheets: Procedure and some applications. Proc Natl Acad Sci USA 1979; 76: 4350-4.

32 von der Mark K, Risse G. Isolation and characterization of laminin receptors. Methods Enzymol 1987; 144: 490-507.

33 McConahey PJ, Dixon FJ. Method of trace iodination of protein for immunological studies. Int Arch Allergy Appl protein for immunological studies.

34 Horwitz A, Duggan K, Greggs R, Decker C, Buck C. The cell substrate attachment (CSAT) antigen has properties of a receptor for laminin and fibronectin. $\mathcal{F}$ Cell Biol 1985; 101 $2134-44$

35 Runyan RB, Versalovic J, Shur BD. Functionally distinc laminin receptors mediate cell adhesion and spreading: The 
requirement for surface galatosyltransferase in cell spreading. F Cell Biol 1988; 107: 1863-71.

36 Graf J, Iwamoto Y, Sasaki M, et al. Identification of an amino acid sequence in laminin mediating cell attachment, chemotaxis, and receptor binding. Cell 1987; 48: 989-96.

37 Iwamato Y, Robey FA, Graf J, et al. YIGSR, a synthetic laminin pentapeptide, inhibits experimental metastasis formation. Science 1987; 238: 1132-4.

$38 \mathrm{Hahn}$ U. Extracellular matrix proteins in small-intestinal cell cultures. Scand $\mathcal{F}$ Gastroenterol 1988; 23 [suppl 151]: 70-8.

39 Daneker GW, Mercurio AM, Guerra L, et al. Laminin expression in colorectal carcinomas varying in degree of differentiation. Arch Surg 1987; 122: 1470-4.

40 Hahn U, Schuppan D, Hahn EG, Merker HJ, Riecken EO Intestinal cells produce basement membrane proteins in vitro. Gut 1987; 28 [suppl 1]: 143-51.

41 Simon-Assmann P, Boutziges F, Daviaud D, Haffen K, Kedinger $M$. Epithelial-mesenchymal interaction in the Kedinger $M$. Epithelial-mesenchymal interaction in the
production of basement membrane component in the gut. production of basement memb

42 Nagai Y, Sunada H, Sano S, et al. Biochemical and immunohistochemical studies on the scirrhous carcinomas of human stomach. Ann NY Acad Sci 1985; 460: 321-32. 